University of California, Hastings College of the Law

UC Hastings Scholarship Repository

Faculty Scholarship

2017

Re-centering Justice as the End Goal of Our Struggle

George Bisharat

Follow this and additional works at: https://repository.uchastings.edu/faculty_scholarship 


\title{
Re-centering Justice as the End Goal of Our Struggle
}

\author{
George Bisharat*
}

Law always has two faces: the face of justice and the face of power. My message this afternoon is simple: that in envisioning alternative futures in Israel/ Palestine, while we cannot afford to neglect law, it is justice that must always remain our guiding light.

This may strike you as a platitude: no one opposes justice. But I would not raise it here if there were not strong evidence that this central pillar of our movement has been obscured.

In particular, the quest for a state that began as a means to realize Palestinian rights has morphed into a quest for a state as an end in itself, virtually without regard to the nature of that state nor its capacity to actually accomplish justice for Palestinians. We have two Palestinian regimes with authoritarian tendencies, that seem more likely to serve as coffins for the burial of Palestinian rights than vessels for their fulfillment.

Re-centering justice at this time is both a moral imperative and a pragmatic political necessity.

But beyond this general call, I also suggest a more multi-faceted conception of justice than we have fielded in the past. So I am not just advocating a return to the sense of justice that animated the movement for Palestinian rights historically. I am also proposing that we expand to a more encompassing one call it a 21st century justice reboot.

* George E. Bisharat is an Emeritus Professor of Law at the University of California Hastings College of the Law, and a former deputy public defender in San Francisco. In addition to his academic publications, he is a frequent commentator on law and politics in the Middle East for both print and broadcast media throughout the globe. This piece is based on a presentation delivered by the author at the conference titled "The State of Israel and International Law: Legitimicacy Exceptionalism and Responsibility", held between the 31st of March and the 2nd of April 2017 at University College Cork, a constituent university of the National University of Ireland. 
Here's how I will proceed:

First, a few words about justice in the early days of the Palestinian movement.

Then, I will explain why I claim that justice is both a moral imperative and political necessity.

Following that, I will briefly review seven facets of justice that we might be wise to consider.

I will finish with a few words about the role of international law and question whether its capacity to deliver justice for Palestinians and others would be enhanced by a principle of state illegitimacy.

The Palestinian opposition to Zionist colonization began as a struggle for justice, first and foremost against the forced displacement of Palestinians in favor of Zionist settlers and the denial of our right to return - commemorated in what we call the Nakba. In truth, the Nakba, defined as the forced displacement of Palestinians for Jewish settlement, continues, as several have observed here, albeit in shifting forms.

The struggle for justice, therefore, has been at its core a struggle to halt the Nakba and to reverse its effects to the maximum extent possible. Understandably, it has focused on righting the wrongs committed against the Palestinian people.

But Palestinians have also embraced broader goals. Particularly in the Palestine Liberation Organization's early adoption of its goal of a democratic secular state in Palestine, we upheld a vision of a progressive society in which all peoples could live in peace, security, and prosperity under a regime of equal rights and mutual respect.

That was the vision that, in the early days of our movement, captured the imaginations of millions throughout the world.

Why is re-centering justice as our end goal a prescription for the ills we currently face, especially as we witness the Zionist colonizing juggernaut rolling forward, with nothing on the horizon to even slow its advance? Does it make sense to double down on justice and even expand our ambitions when we have failed to achieve justice in even a minimal form? Is it right to affirm tolerance and inclusion against the headwind of rising right-wing ethnic nationalism, in which Israel is ahead of the global curve by a decade or two?

These are serious questions. My instinct is that part of our current weakness is precisely that we have been too compromising on matters of principle. The result has been the internal division and deflation of our movement, and lesser international solidarity. Our soft power, to recall Richard Falk's phrase, can only be enhanced by adopting a broad vision of justice.

But invoking "justice" in the abstract is not enough. So here are seven facets or dimensions of justice that, to my mind, merit consideration. This list is provisional and not exhaustive. 
The first is original justice - by this I mean that while a broader conception of justice is called for today than in the past, the original core rights of the Palestinian people remain the bedrock of a just resolution. It is the Palestinians who were the first and remain the primary victims of Zionism, and whose rights remain in most urgent need of restoration. We are building on, not discarding, earlier conceptions of justice.

I underscore here that I mean the entire Palestinian people, including the majority who are refugees living in internal or external exile and those who live as second-class citizens within Israel.

Early on, Palestinians recognized that justice for us could not be injustice for others, but there is a need to more fully elaborate a conception of what might be called protective justice. We would benefit by a compassionate declaration along the lines of South Africa's Freedom Charter outlining how our conception of justice also includes Israeli Jews, who will continue to inhabit Israel/Palestine.

Whether the land is shared in one state, two, or two dozen, we need a vision of a future society that respects and strives for justice for all. The more concrete we can be, the better - for example, in addressing the status and rights of secondary occupants (Israeli Jews) who currently inhabit former Palestinian homes, and to outline a process that treats them justly and with respect and dignity.

We also must think beyond the binary of Israeli Jews/Palestinian Arabs, which flattens and masks diversity on both sides. There are many considerations here, but the salient one to me involves Mizrahi Jews, who I would count as Zionism's second major category of victims. From the destabilization of their communities in the Arab world that Zionism caused, to the discrimination and racism those who settled in Israel have faced from Jews of Ashkenazi descent, Mizrahi Jews have suffered largely in obscurity. Mending their wounds will be a complex challenge and, in part, implicates regional considerations, to which I will return shortly.

South Africa provides us a model for thinking about other facets of justice as well. South Africans conducted a partially successful experiment in what is sometimes called transitional justice.

While our transition still lies ahead, we can start conceptualizing how we will deal with truth and reconciliation. There is scope for acknowledgments and apologies for suffering inflicted on multiple sides, including by Palestinians.

Post-apartheid South Africa, as you also doubtlessly know, is riven with problems of crime and deep social and economic inequalities. Many critics of the transition from apartheid trace these problems to the failure to consider questions of social justice in that transition. 
Israel suffers acute income inequality, as became vividly apparent in the 2011 protest movement in Tel Aviv. The neoliberal policies of the Palestinian Authority have also exacerbated deep class divisions in the West Bank. Poverty rates in the Gaza Strip are terrible, due to the ruinous siege now in its tenth year, three major Israeli attacks, and nearly continuous low grade violence. Out of this, how do we not just end the Nakba, but also build a humane society in which any of us would be proud to live?

Gender and sexual preference justice, both Israeli and Palestinian societies, manifest patriarchy and sexual preference oppression in their specific ways. This is not just me importing my San Francisco values to Israel/Palestine. Rather, I take my cue from local feminists and queers. On the Palestinian side, women have long been expected to subordinate gender rights to national struggle, for no good reason. We must stand for gender and sexual preference justice everywhere, and now.

In a place where injustices against humans abound, it is easy to neglect damages to the natural environment. Gaza, as you no doubt have read, may well be unlivable from an environmental perspective as soon as 2020, according to some experts. So we must account at some level for environmental justice.

Israel has alternately plundered the occupied Palestinian territories of water or stone, and used them as dumping grounds for pollutants. Neither has the Palestinian Authority proved itself a responsible steward of the environment. Yet justice to the land, if we may call it that, is a matter of urgent concern to all life in the region.

This brings us to the last facet of justice I will address today, namely regional justice. Israel has inflicted harm in varying degrees on all of its neighbors at one time or another. Just to start, Israel cast hundreds of thousands of destitute refugees onto neighbors ill-equipped to absorb them. Arab societies were disfigured, robbed of vitality and diversity, by the loss of their Jewish communities following Israel's establishment. And while the circumstances of the departures of Mizrahi Jews from Arab countries varied widely, there is no doubt that some suffered grave injustices that should be acknowledged and rectified.

Is consideration of these multiple facets of justice premature? Possibly. But the more we flesh out the meaning of justice, the more we will ignite support and enthusiasm. We can offer the world the model of another Arab police state, or two, as the case may be; or one of an enlightened and just society, that fosters diversity and sustainability in our relationship to the natural environment. Which do you think is more likely to inspire support, and to mobilize people to action? 
Now to the last part of my presentation, about the role of international law as a medium for accomplishing justice and whether it should include a principle of state illegitimacy.

It may surprise you to learn that I, an organizer of this conference, came here agnostic as to that question. Frankly, I doubt that international law currently lacks the tools to encourage justice in Israel/Palestine. Many liberation struggles, including the struggle against apartheid, have succeeded without a principle of state illegitimacy.

Here we have to be careful not to be bewitched by law's promise - not to expect law to outrun politics, and deliver victories that have not been earned on the field of political struggle. I say this because some of us may have high expectations, for example, of the International Criminal Court.

I recently visited the United States National Civil Rights Museum in Memphis, Tennessee, housed in the Lorraine Hotel, where the Reverend Martin Luther King was assassinated in 1968. I was struck in particular by a quote I read there from Bayard Rustin, a prominent strategist of the civil rights movement that said:

Unjust social laws and patterns do not change because supreme courts deliver just decisions ... Social progress comes from struggle: all freedom demands a price.

Rustin reminds us that courts make socially and politically progressive decisions only when forced to do so by a mobilized citizenry. This, I would argue, is just as true of international courts as it is of domestic courts. So we must be guarded in our expectations of what to expect from law.

This is far from saying, however, that international law is inconsequential. No South African official was ever tried under the International Convention on the Suppression and Punishment of the Crime of Apartheid, but its adoption by the United Nations General Assembly in 1973 was surely not an idle act. On the contrary, it dramatically expressed the moral outrage of a segment of the international community that helped to transform public discourse about South African apartheid. The same is true of Richard Falk's and Virginia Tilley's recent report on Israel's treatment of the Palestinian people as constituting the crime of apartheid - which is precisely why it has been officially suppressed.

Law may not deliver us salvation. We who work in the legal field must put our shoulders to the wheel along with others pushing in their own domains. In other words, if we effectively integrate the legal with other forms of struggle, justice will at least come a little closer. 